\title{
The Dark Side of Covid. A Critical Sociologic Viewpoint
}

\author{
Mariano Dimonte* \\ Radiology Department, City Hospital, 73020 Scorrano, ASL Lecce, Italy \\ *Corresponding author: Mariano Dimonte, Radiology Department, City Hospital, 73020 Scorrano, ASL Lecce, Italy
}

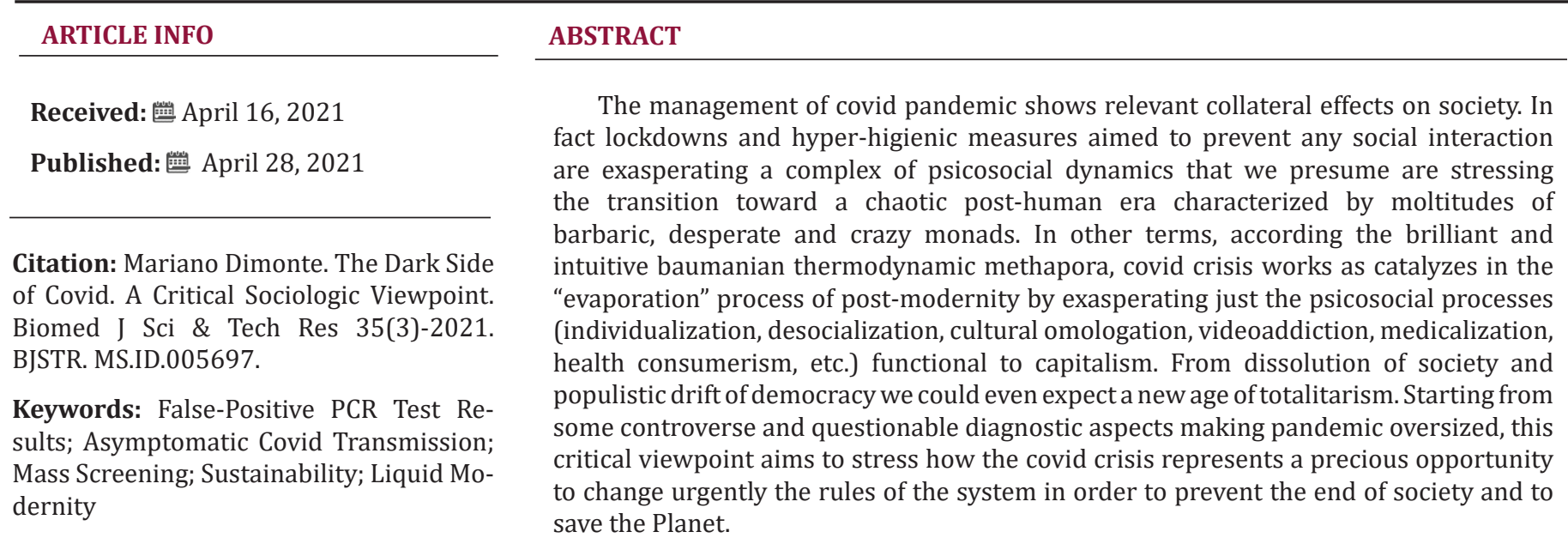

Abbreviations: PCR: Polymerase Chain Reaction; Ct: Cycle Threshold

\section{Introduction}

Universally the governments have adopted anti-social and ultra-higyenic measures aimed to counter the spread of covid and prevent the collapse of healthcare system, but also to promote the mass in vivo experimentation of the vaccines [1]. However the dominant epidemic paradigma inspiring lockdowns, closures and suspension of the basic human rights is based on controverse and questionable diagnostic aspects. Today, more than one year after the beginning of the emergence, except for accidental and unexpected beneficial effects on climate, we can observe the amount of collateral effects on society of unsucessful policies adopted by technocratic governments unprepared and incapable to stem global dangers [2]. Starting from data emerging from a minority literature, I support the idea of an oversized pandemic allowing governments to exploit the crisis in order to consolidate neoliberistic and autocratic drifts by mean of the fear, and in parallel to devert the attention from the Sustainability issues. In addition many reflections warn us how covid is catalyzing the transition from the late modernity to a post-human condition characterized by moltitudes of barbaric, desperated and crazy monads. These distressing changes makes this crisis a precious opportunity to urgently change the rules of the system if we want to prevent end of society, onset of a new age of totalitarism, and to save the Planet

\section{A “Test, Test, Test”Constructed Pandemic}

The reverse transcriptase-polymerase chain reaction (PCR) tests performed on the general population play a crucial role in the management of covid crisis. In fact this molecular test detecting viral genes from the nasopharingeal swabs shows a practical accuracy lesser than $90 \%$ becouse of an amount of limits and pitfalls [3]. In particular an eventual positive result in asymptomatic people who has not been in close contact with patients suffering from covid doesn't inform at all about the real infectivity of the subject tested becouse the most of asymptomatic cases have a minimal viral load and failed in vitro cultures. For this reason rather a qualitative binary result (positive/negative) we need to quantitate the viral load: lower the cycle threshold (Ct) value, higer the viral load and viceversa. If $\mathrm{Ct}$ value is over 35 and if only one viral gene out three is amplified it's unlike that an asymptomatic subject can be an infector. Inert viral fragments, cross-reactions toward coronavirus- 
like antigens, contamination of reagents during the transportation of samples and "pooling" procession are reported as the most common causes of artifacts [4,5]. Moreover, according the Bayes's formula, the ignorance of pre-test probability and prevalence due to mass screenings without scrutiny affects the reliability of the results [4].

In essence the rate of false positive results from mass screenings performed during periods of low prevalence can reaches $50 \%$ [6]. A study conducted at Whuan on 10 million people reports a rate of false positive results of $36.7 \%$, confirmed by failed viral coltures and lack of immuno response [7]. Other studies warn us about epidemic trends inflated by significant amounts of diagnostic errors, only qualitative and no-retested dobious results [8-11]. Paradoxically these errors contribute to overload the healthcare system, apart from the unfair confinement of the subject tested and his close contacts.

\section{Hunt for the Occulted Spreader}

Despite a "state-of-war" rhetoric, in tha vast maiority of cases covid-19 is a silent or a mild flu-like disease, while hospitalization is required for a $10 \%$ of patients. A minimun fraction of patients suffering from SARS dyes becouse of older age and/or concomitant debilitating conditions [12-14]. At the present in Italy the presumed victims of covid-109 are 75.891, and in every istant media let we know the daily number of deaths. But likely very few know that annually die 230.000 italians becouse of cardiovascular diseases and 180.000 becouse of cancer (source: ISTAT, 2017). That is most people prematurely die becouse of environmental and social distress-related pathologies. The representation of covid nullified any other reality; it monopolized information; it is making us forget that the Planet is seriusly sick. Among the darkest sides of a disconcertant storytelling has to be included the surprising fact that, whereas the unaware people are believed to be silent infectors, at the same time natural immunity is believed not protective and everybody has to be vaccined by experimental drugs believed to be not fully effective. In particular, about the asymptomatic transmission of covid data seem quite controverse. In fact, although is reported an occult viral transmission up to $88 \%$ of cases, YanesLane's group stresses the concept that if PCR Ct value is over 30, viral RNA concentration is below 100.000 copies $/ \mathrm{ml}$, and only one gene out three is amplified, the inter-human trasmission of a significant viral load is very unlikely [15].

The most of the close contacts of sick passengers on board of the Diamond Princess cruise ship just resulted covid-free [16]. In large samples of asymptomatic index-cases some studies proved no one secondary infection [17-19]. Early USA CDC guidelines highlighted the unusefulness of mass screenings and of testing close contacts of asymptomatic index-cases [20]. [21,22], some observers arise doubts about inappropriate and more and more expansive screening campaigns without scrutiny [23-25]. A Sweden study documenting a higher mortality rate in countries which in the first wave adopted rigid lockdowns makes us reflecting about the crucial role of good home cares [26]

\section{Gainers and Losers in Times Like This}

A part from failure of international cooperation, lack of updated anti-flu protocols, unpreparadness of mcdonaldized healthcare systems, covid unmasked the extreme fragility of globalization, so that local events can quickly spread worldwide becoming uncntrolled "blackswan". Now China, USA, Korea, Japan and Western Europe, togheter accounting for $65 \%$ of gross world product, have to face the collateral effects of improvised draconian lockdowns [27-29]. Entire sectors (transportation, tourism, hospitality, sport, culture, housing, catering, leisure) collapsed; families overloaded by the additional costs emerging from closure of the schools and digital tools for remote learning; investments postponed; hirings suspendend [30]. Fortunately the air levels of PM, NO2 and CO2 decreased in comparison with 2019, despite the inceneration of growing volumes of nonrecyclable plastic disposals, making air cleaner and many ecosystems recovered [31,32]. Not by a chance covid hit just the regions where industrialization and urbanization are higher. But if the Planet accidentally and unexpectedly benefits from the recession, covid could even trigger an epochal change by accelerating the end of late modernity. In essence, by destroying society covid heralds a post-human world characterized by swarms of isolated and lonely monads wandering aimlessly. In fact lockdowns, confinements and social distancing are accelerating the atomization of society making more and more fragile, precarious, flexible, fragmented, virtualized the social ties. In a society forced to stay at home, keep a safe distance, avoid encounters, wear a mask, inevitably the residual shreds of solidarity are destined to dissolve.

Following the brilliant and intuitive Bauman's termodinamic methapora, covid risk to "evaporate" a society in an advanced state of liquefaction projecting the humans toward a new chaotic desocialized condition [33]. Digitalization plays a crucial role in making society increasing atomized, hyper-egoic, cultural regressed, and covid is favoring $5 \mathrm{G}$ applications making healthcare more and more de-humanized and world capillarly surveilled [34]. In addition isolation, solitude, fear, uncertainty, poverty, social distress are spreading worldwide a sort of collective madness [35]. But exploiting the pandemic unelected, populist and technocratic governments are also making people more and more docile, obedient, resigned, omologated, in order to prevent eventual ribellions. And the step from populism to totalitarism, riding on social disintegration, is very short [36].

\section{Final Considerations}

In extreme essence the covid crisis impose us to try urgently the ways to make economy sustainable, recover democracy, renaturalize the life. By Nemesi Medica (1974) Ivan Illich explained 
that the growing complexity of the business-oriented healthcare is socially iatrogenic. More recently Lewis and Maslin (The Human Planet: how we created the Antropocene; 2018) and Harari (Homo Deus; 2015) documented how from artificial intelligence, nanotechnology, bioengeenering, robotics, 5G applications can be generated unpredictable and uncontrolled catastrophic reactions. But was Karl Marx in the far 1864 to predict that the capitalist system would be implosed just becouse of own ontologic unsustainability, and likely the covid will increase more and more the distance also from the targets fixed by the 2015 Paris Agreement.

\section{References}

1. Boschele M (2020) Covid-19 science policy, experts, and publics: why epistemic democracy matters in ecological crises. Omics 2020 24(8): 479-482.

2. Ibn Mohammed T, Mustapha KB, J Godsell, Z Adamu, KA Babatunde, et al. (2021) A critical analysis of the impacts of covid on the global economy and ecosystems and opportunities for circular economy strategies. Resources, Conservation \& Recycling 164: 105169.

3. Velavan TP, Meyer CG (2021) Covid-19: a PCR-defined pandemic. Int ] Infectious Diseases 103: 278-279.

4. Jaeger LH, Nascimento TC, Fabíola Dutra Rochaa, Fernanda Maria Pinto Vilelaa, Ana Paulado Nascimento Duquea, et al. (2020) Adjuting RT-qPCR conditions to avoid unspecific amplification in SARS cov2 diagnosis. International Journal of Infectious Deseases 102(2021): 437-439.

5. Afzal A (2020) Molecular diagnostic technologies for covid19: limitation and challages. Journal of Advanced Research 26: 149-159.

6. Esteve C, Catherine FX, P Chavanet, M Blot, L Piroth (2020) How should a positive PCR test result for covid-19 in an asymptomatic individual be interpreted and manged. Medecine et maladies infectieuses 50(8): 633638.

7. Gao M, Yang L, Xuefu Chen, Yiyu Deng, Shifang Yang, et al. (2020) A study infectivity of asympromatic SARS-Cov- carriers. Respiratory Medicine 169: 106026

8. Braunstein GD, Schwartz L, Pamela Hymel, Jonathan Fielding (2021) False positive results with SARS-CoV-2 RT-PCR tests and how to evaluate a RT-PCR positive test for the possibility of a false positivie result. J Occupational and Environmental Medicine 63(3): e159-e162.

9. Basile K, Maddocks S, J Kok, DE Dwyer (2020) Accuracy amidst ambiguity: false positive SARS-CoV-2 nucleic acid tests when covid-19 prevalence is low. Pathology 52(7): 809-823.

10. Healy B, Khan A, Huria Metezai, Ian Blyth, Hibo Asad (2021) The impact of false positive covid-19 results in an area of low prevalence. Clinical Medicine 21(1): e54-e56.

11. Katz AP, Civantos FJ, Zoukaa Sargi, Jason M Leibowitz, Elizabeth A Nicolli, et al. (2020) False positive reverse transcriptase polymerase chain reaction screening for sarscov2 in the setting of urgent head and neck surgery and orl emergencies during the pandemic: clinical implications. Head \& Neck

12. Cevik M (2020) Virology, transmission and pathogenesis of sars cov2. BMJ 371: $\mathrm{m} 3862$.

13. Healy B, Khan A, Huria Metezai, Ian Blyth, Hibo Asad (2021) The impact of false positive COVID-19 results in an area of low prevalence. Clinical Medicine 21(1): e54-56.
14. Nakajo K, Nishiura H (2021) Transmissibility of asymptomatic COVID-19: data from japanese clusters. Int J Infectious Diseases 105(2021): 236238.

15. Yanes Lane M, Winters N, Federica Fregonese, Mayara Bastos, Sara Perlman Arrow, et al. (2020) Proportion of asymptomatic covid-19 infections: a systematic review and meta-analysis. Plos One.

16. Sakuri A, Sasaki T, Shigeo Kato, Masamichi Hayashi, Sei Ichiro Tsuzuki, et al. (2020) Natural History of asymptomatic SARS-CoV-2 infection. NEJM 383(9).

17. Jia X, Junxi Chen, Liangjing Li, Na Jia, Bahabaike Jiangtulu, et al. (2020) Modeling the prevalence of asymptomatic covid-19 infections in the chinese mainland. The Innovation 1(2): 100026.

18. Jung CY, Park H, Dong Wook Kim, Yoon Jung Choi, Seong Woo Kim, et al. (2020) Clinical characteristics of asymptomatic patients with covid-19: a nationwide cohort study in South Corea. Int J Infectious Diseases 99: 266-268.

19. He D, Yang L, Shi Zhao, Qianying Lin, Zian Zhuang, et al. (2020) The relative transmissibility of asymptomatic covid-19 infections among close contacts. Int J Infectious Diseases 94: 145-147.

20. Schuets AN, Hemarajiata P, Ninad Mehta, Sheldon Campbell, Stephanie Mitchell, et al. (2021) When should asymptromatic persons be tested for covid-19? J Clinical Microbiologt 59(1): e02563-2620.

21. Lampl BMJ, Salzberger B (2020) Changing epidemiology of covid-19. GMS Hygiene and infection control 15: 2196-5226.

22. Munro APS, Faust SN (2020) Children are not covid-19 super spreaders: time to go back to school. Arch Dis Child 105(7): 618-619.

23. Nogrady B (2020) What the data say about asymtomatic covid infections. Nature 587(26).

24. Abbasi K (2020) Covid-19: screening without scrutiny, spending taxpayers billions. BMJ 371: $\mathrm{m} 4487$.

25. Abbasi K (2020) The democratic, political and scientific failure of covid19. BMJ 371: $\mathrm{m} 4277$.

26. Giesecke J (2020) The invisible pandemic. Lancet 395(10238).

27. Nicola M, Alsafi Z, Catrin Sohrabi, Ahmed Kerwan, Ahmed Al Jabir, et al. (2020) The socio-economic implications of the coronavisrus pandemic (Covid-19): a review. International Journal of Surgery 78: 185-193.

28. Baldwin R, Evenett S (2020) Covid-19 and trade policy: why turning inward won't work

29. Ricolfi L (2021) La notte delle ninfee. Come si malgoverna una epidemia. La nave di Teseo, Milan.

30. Sharma I, Vashnav M, Reet Sharma (2020) Covid-19 pandemic hype: losers and gainers. Indian J Psichiatry 62(9): S420-S430.

31. Ching J, Kajino M (2020) Rethinking air quality and climate change after covid-19. Int J Environ Res \& Public Health 17(14): 5167.

32. Cheval S, Adamescu M, Teodoro Georgiadis, Mathew Herrnegger, Adrian Piticar et al. (2020) Observed and potential impacts of covid-19 pandemic on the environment. Int J Res Public Health 17(11): 4140.

33. Dimonte M (2020) The counterproductive side effects of 5G. Considerations in times of pandemic. JPM 5(2): 06.

34. Bordoni C (2021) L'intimità pubblica.

35. Manacorda E (2021) "Covid: suicidi in aumento". La Repubblica.it.

36. Wu AHB (2020) Screening the general population for SARS-CoV-2 virus and covid-19 antibodies: a counterargument. JALM 5(5): 1107-1110. 


\section{ISSN: 2574-1241}

DOI: $10.26717 /$ BJSTR.2021.35.005697

Mariano Dimonte. Biomed J Sci \& Tech Res

(c) (P) This work is licensed under Creative

Submission Link: https://biomedres.us/submit-manuscript.php

$\begin{array}{ll}\text { BIOMEDICAL } & \text { Assets of Publishing with us } \\ \text { RESEARCHES } & \text { - Global archiving of articles } \\ & \text { - Immediate, unrestricted online access } \\ & \text { - Rigorous Peer Review Process } \\ & \text { - Authors Retain Copyrights }\end{array}$

